\title{
Five new species of Pseudorhabdosynochus (Monogenea: Diplectanidae) from the gills of Epinephelus costae (Teleostei: Serranidae)
}

\author{
Lassâd Neifar ${ }^{1}$ and Louis Euzet ${ }^{2}$ \\ ${ }^{1}$ Laboratoire de Bioécologie Animale, Département des Sciences de la Vie, Faculté des Sciences de Sfax, BP 802, 3018, Sfax, \\ Tunisia; \\ ${ }^{2}$ Station Méditerranéenne de l'Environnement Littoral, 1 Quai de la Daurade, 34200, Sète, France
}

Key words: Monogenea, Diplectanidae, Pseudorhabdosynochus bouaini, Pseudorhabdosynochus dolicocolpos, Pseudorhabdosynochus enitsuji, Pseudorhabdosynochus sinediscus, Pseudorhabdosynochus sosia, gill parasite, Epinephelus costae, Serranidae, Tunisia, Senegal

\begin{abstract}
A survey of the gill parasites of Epinephelus costae (Teleostei: Serranidae) was conducted between 2001 and 2005 in the Gulf of Gabès (Tunisia). Five new species of Diplectanidae (Monogenea) were collected, all belonging to Pseudorhabdosynochus Yamaguti, 1958: P. bouaini sp.n., P. dolicocolpos sp.n., P. enitsuji sp.n., P. sinediscus sp.n., and P. sosia sp.n. These five species differ from each other and from all described species of Pseudorhabdosynochus by the morphology and size of their sclerotized vagina. These diplectanids (except $P$. sinediscus) were also collected from the same host off Dakar in 1981 and 1989. The present paper includes the descriptions and taxonomic considerations of each of these species in addition to an amended diagnosis of Pseudorhabdosynochus. A key to the five new species parasitizing E. costae is provided. These five species are the first diplectanids described from E. costae.
\end{abstract}

Groupers, Epinephelus spp. (Serranidae: Epinephelinae), are mostly found in tropical and subtropical seas. Only 7 of the 99 species described in the genus have been reported from the Mediterranean Sea and the eastern Atlantic Ocean (Heemstra and Randall 1993). Two species, E. coioides (Hamilton, 1822) and E. malabaricus (Bloch et Schneider, 1801) are rare Lesseptian fish and no parasitological information has been reported for them in the Mediterranean. Five species, E. aeneus (Geoffroy Saint Hilaire, 1817), E. caninus (Valenciennes, 1843), E. costae (Steindachner, 1878), E. haifensis Ben Tuvia, 1953, and E. marginatus (Linnaeus, 1758), are more common on the meridional coast of the Mediterranean Sea, and in the eastern Atlantic Ocean. All of these species are of considerable importance to artisanal and commercial fisheries and have been listed as potentially interesting species for marine aquaculture in the Mediterranean (FAO 1997). Monogenean infections have already been reported for numerous grouper species in aquaculture (Tak-Seng and See-Yong 1988, Bu et al. 1999, Santos et al. 2000), and knowledge of monogeneans is fundamental before beginning any aquaculture project.

Epinephelus aeneus and E. marginatus are known as hosts of diplectanids (Oliver 1987), but no parasitological data have been reported from E. caninus, E. costae and E. haifensis. Epinephelus costae is commonly caught along the southeastern coast of Tunisia (Gulf of Gabès). During a parasitological study, between February 2001 and March 2005, five new diplectanids be- longing to Pseudorhabdosynochus Yamaguti, 1958 were found parasitizing the gills of this grouper. Four of these diplectanids were in the collection of L. Euzet from material collected, from the same host, in the eastern Atlantic (Senegal) by J.-L. Justine in 1981 and A. Raibaut in 1989. The present paper includes descriptions of these five species, in addition to an amended diagnosis of Pseudorhabdosynochus.

\section{MATERIALS AND METHODS}

Specimens of Epinephelus costae caught by local fishermen were examined shortly after death. Gills were removed and placed in separate Petri dishes containing seawater and examined for parasites under incident light, using stereomicroscope. Monogeneans were detached from the gills with a strong water current or picked up with fine needles and transferred to a dish containing seawater. Live parasites were partially compressed beneath a coverslip and examined using a compound microscope. Some parasites were transferred individually onto a slide in a drop of ammonium picrate-glycerine (Malmberg 1957). The preparation was then covered with a round coverslip and sealed with Canada balsam. Other specimens were fixed between slide and coverslip with $5 \%$ buffered neutral formaldehyde or $75 \%$ ethanol, and stored in $75 \%$ ethanol. These parasites were stained with Grenacher boracic carmine or Semichon acetic carmine, dehydrated using a graded ethanol series, cleared with clove oil, and mounted in Canada balsam. Slides from Senegal were stained with Semichon acetic carmine or hemalum-eosin and mounted as described above. Some live specimens mounted in Berlese were 

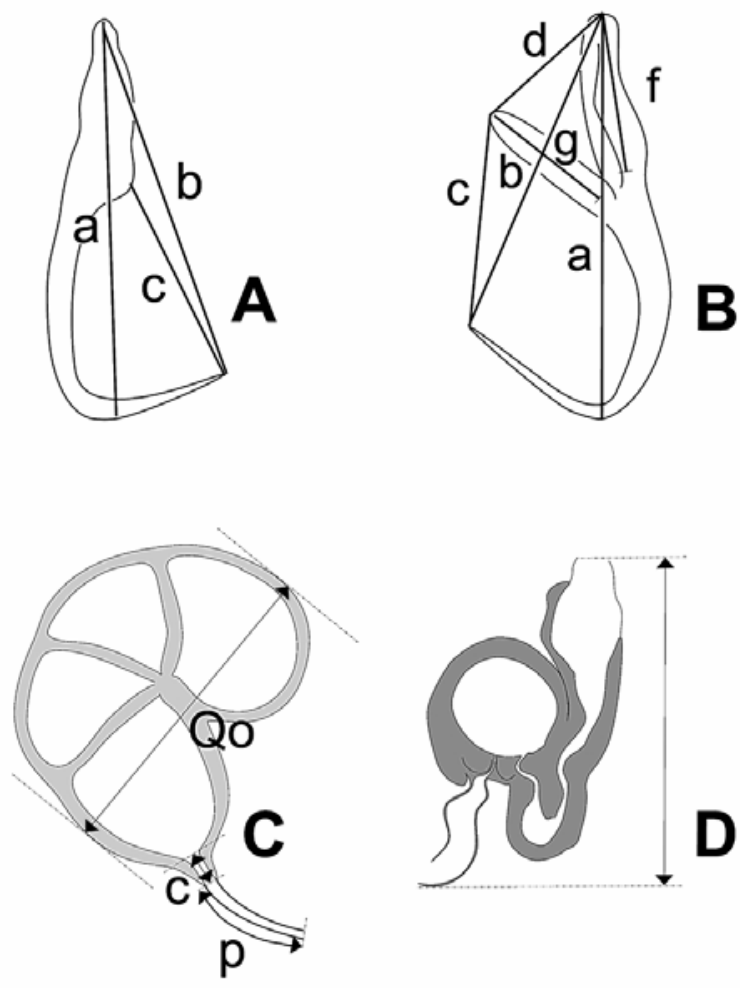

Fig. 1. Methods of measurements of various sclerotized organs. A - dorsal anchors; B - ventral anchors; C - male quadriloculate copulatory organ (Qo - quadriloculate organ; c cone; $\mathrm{p}$ - tube); D - sclerotized vagina.

used to view the morphology of the haptoral sclerites and the copulatory complex. Illustrations and measurements were made with the aid of a Leitz microscope equipped with a drawing tube. All measurements were made on live worms partially compressed beneath a coverslip and are given in micrometres as the range followed in parentheses by the mean, the standard deviation, and (n) the number of observations. Measurements of anchor pairs follow the scheme proposed by Gussev (1962) and adapted by Euzet and Oliver (1966) (Fig. 1). Measurements of the male copulatory organ and sclerotized vagina are illustrated in Fig. 1. Drawings were scanned and redrawn on a computer with CorelDraw software. Museum abbreviations used are as follows: MNHN, Muséum National d'Histoire Naturelle, Paris; BMNH, Natural History Museum, London, and IPC, Institute of Parasitology, Academy of Sciences of the Czech Republic, České Budějovice. The following material was examined: syntype of Cycloplectanum beverleyburtonae Oliver, 1984, MNHN, nos. $249 \mathrm{H}-\mathrm{Tc}$ 167 and 167 bis.

\section{RESULTS}

\section{Pseudorhabdosynochus bouaini sp. n.}

Fig. 2.

Description (based on 16 flattened specimens). Diplectanidae, Diplectaninae. Adults 1,150-1,800 (1,470 \pm $116, \mathrm{n}=11)$ long, including haptor; maximum width $300-500(390 \pm 37, \mathrm{n}=11)$ at level of ovary. Tegument smooth. Two groups of cephalic glands lateral to pharynx, both with numerous ducts leading to three prominent apertures which open ventrally on either side of lateral margin of head (head organs). Two pairs of dorsal ocelli, anterior pair smaller. Mouth anterior, subterminal ventral. Pharynx median, subspherical, 80-120 (92 $\pm 7, \mathrm{n}=13)$ long, 65-95 $(75 \pm 6, \mathrm{n}=13)$ wide. Oesophagus very short; oesophageal glands present. Two simple lateral intestinal caeca not united posteriorly. Haptoral peduncle present. Haptor trapezoidal. Dorsal and ventral squamodiscs elliptical, 90-110 (101 $\pm 5, \mathrm{n}=$ 8) long, 100-120 (109 $\pm 5, \mathrm{n}=8)$ wide, with 14-16 (15 $\pm 1, \mathrm{n}=9$ ) concentric rows of rodlets; 1-2 innermost rows V-shaped and closed. Dorsal anchors with incipient guard, straight blade and short point; a: 46-62 (58 \pm $2)$, b: 45-61 (55 \pm 2$)$, c: 25-31 $(26 \pm 1), \mathrm{n}=16$. Two lateral dorsal bars, with spatulate medial end, 75-90 (80 $\pm 3, \mathrm{n}=16)$ long, $12-15(14 \pm 1, \mathrm{n}=16)$ wide. Ventral anchors with developed handle, wide guard, bent shaft and short point; a: $62-70(65 \pm 1), b: 55-65(61 \pm 2)$, c: 37-47 (43 \pm 2$)$, d: $21-32(25 \pm 2)$, f: $12-30$ (18 \pm 3$)$, g: 13-20 $(18 \pm 1),(\mathrm{n}=16)$. Ventral bar 95-130 $(112 \pm 5, \mathrm{n}$ $=16$ ) long, with small constricted median portion, 10 $20(15 \pm 2, \mathrm{n}=16)$ wide. Fourteen uncinuli (seven pairs) 12-13 long; three ventral and two dorsal pairs on lateral haptoral lobes; two ventral pairs between anchors.

Subspherical testis posterior and intercaecal. Vas deferens emerging from antero-sinistral part of testis; seminal vesicle in middle region of the body as conspicuous dilation of vas deferens. Prostatic glands lateral, right prostatic reservoir muscular. Male quadriloculate copulatory organ with reniform bulb divided into four chambers with sclerotized wall, 150-190 (174 \pm 5 , $\mathrm{n}=21$ ) maximum length; first chamber with subcircular zone (aperture?); last chamber forming short cone 15$25(20 \pm 1, \mathrm{n}=21)$ long, extended by thinly sclerotized tube; tube $50-65(55 \pm 2, \mathrm{n}=21)$ long; cirrus sometimes everted at the tip of tubes $(53-55, \mathrm{n}=2)$ long, with subterminal dilation. Ovary on right side, looping dorsoventrally around right intestinal caecum. Vagina on left side of body between ovary and male copulatory organ, 55-75 (62 $\pm 3, \mathrm{n}=16)$ maximum length; vagina with anterior trumpet followed by short heavily sclerotized primary canal, constricted in middle, and connected by thin tube to heavily sclerotized spherical primary chamber $30-40(35 \pm 2, \mathrm{n}=16)$ diameter. Distal part of the primary chamber with two small sclerotized protuberances. (Fig. 2D). Vitelline follicles lateral, coextensive with intestinal caeca, contiguous posterior to testis. Ootype on right side, opening at median genital pore. Eggs reniform with thickest shell at proximal pole, polar filament absent, 150-180 (166 $\pm 18, \mathrm{n}=7)$ long, 55-75 $(62 \pm 3, \mathrm{n}=7)$ wide.

Ty pe host: Epinephelus costae (Steindachner, 1878).

I $\mathrm{n} \mathrm{fect}$ i o n s i t e : Gills, between secondary gill lamellae. Type 1 oc ality: $\operatorname{Sfax}\left(34^{\circ} 45^{\prime} \mathrm{N}, 10^{\circ} 05^{\prime} \mathrm{E}\right)$. 

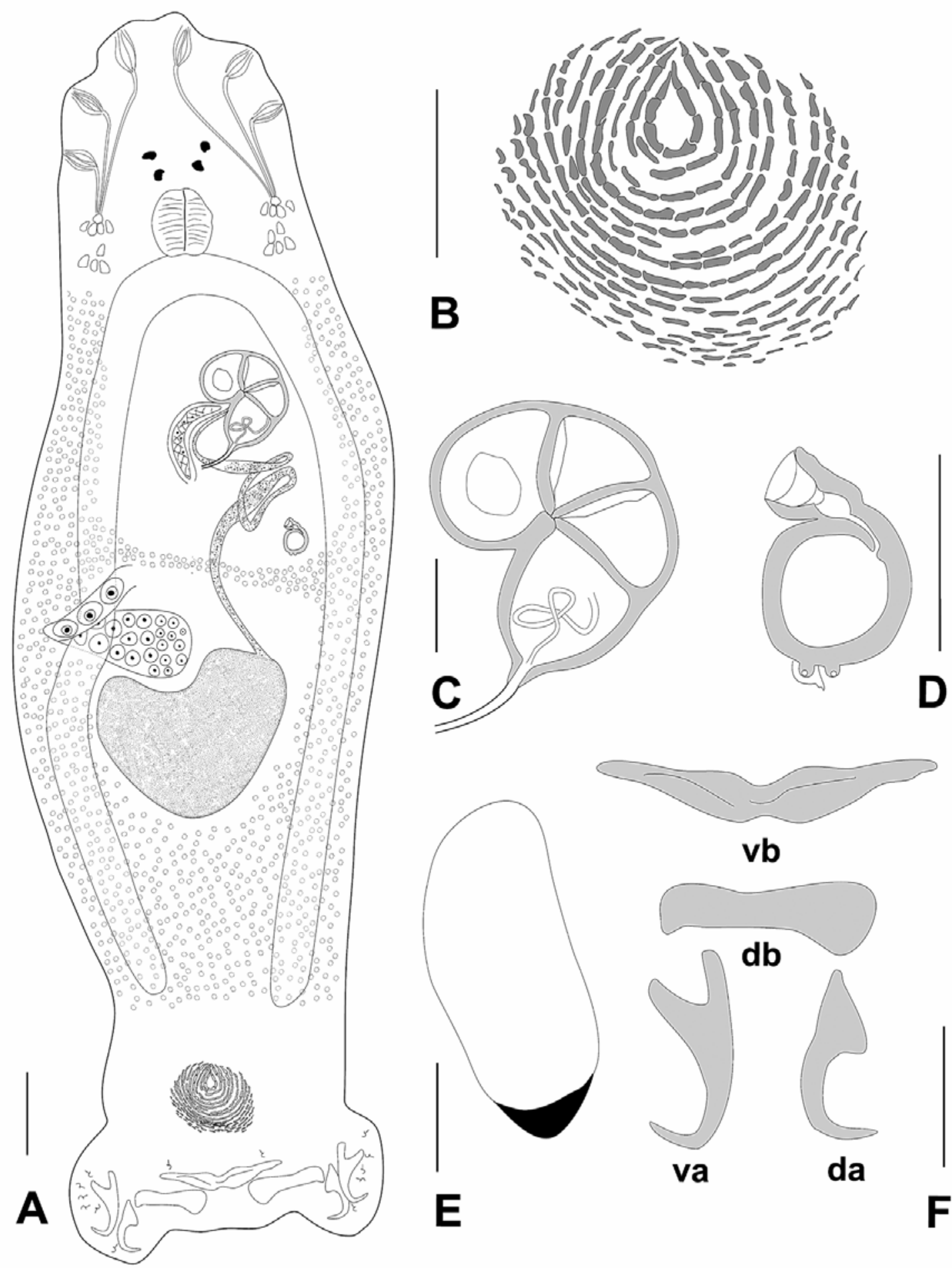

vb
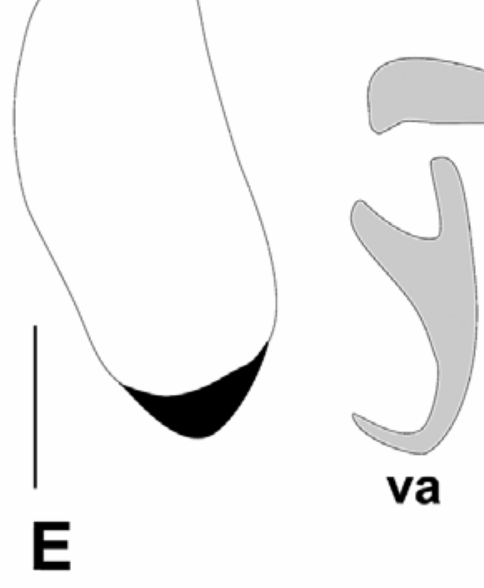

\section{db}

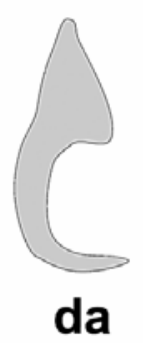

da

Fig. 2. Pseudorhabdosynochus bouaini sp. n. A - habitus, ventral view, composite drawing of live specimens; B - ventral squamodisc; C - male quadriloculate copulatory organ; D - sclerotized vagina; E - egg; F - haptoral sclerite (vb - ventral bar; $\mathrm{db}$ - dorsal bar; va - ventral anchors; da - dorsal anchors). Scale bars: Fig. A $=100 \mu \mathrm{m}$; Figs. $\mathrm{B}-\mathrm{F}=50 \mu \mathrm{m}$.

O t h e r 1 o c a 1 i t i e s : Zarzis $\left(33^{\circ} 15^{\prime} \mathrm{N}, 11^{\circ} 10^{\prime} \mathrm{E}\right)$

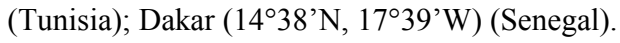

Prevale n c e : $63 \%$ (examined 19 , infected 12 ).

H o 1 o t y p e : MNHN no. HEL 1 (Th 74).
P a r a t y p e s : MNHN no. HEL 2 (Th 75), MNHN no. HEL 3 (Th 76); BMNH no. 2007.3.12.1; IPC no. M-435.

E t y m o log y: This species is named in honour of Professor A. Bouain from the University of Sfax, a specialist in biology of groupers. 


\section{Remarks}

Pseudorhabdosynochus bouaini can be distinguished from all other described species of Pseudorhabdosynochus based on the morphology and the size of its sclerotized vagina, which has a large heavily sclerotized chamber. The vaginae of $P$. capurroi Vidal-Martínez et Mendoza-Franco, 1998 and P. kritskyi Dyer, Williams et Bunkley-Williams, 1994, (as redescribed by Tingbao et al. 2005), both have a heavily sclerotized chamber, but both lack a protuberance in the distal part of the vagina. Furthermore on squamodisc, 1-2 innermost row of rodlets form complete circle in $P$. bouaini, and the 4 5 innermost rows form complete circle in both $P$. capurroi and $P$. kritskyi.

Just like Pseudorhabdosynochus bouaini, two other species, $P$. auitoe Justine, 2006 and $P$. venus Hissinger et Justine, 2005, have sclerotized vagina with a large primary chamber, but differ from $P$. bouaini by having a secondary canal and a small secondary chamber.

\section{Pseudorhabdosynochus dolicocolpos sp. n.}

Figs. 3, 4

Description (based on 30 flattened specimens). Diplectanidae, Diplectaninae. Adults 650-950 (790 $\pm 58, \mathrm{n}$ = 25) long, including haptor; maximum width 180-350 $(267 \pm 30, n=25)$ at level of ovary. Posterior third of tegument covered with anteriorly directed scales, observed in whole mount only as laterally distributed along the body. Anterior region with three pairs of lateral head organs; two groups of cephalic glands lateral to pharynx, both with numerous ducts leading to head organs; single anteromedian cephalic gland present, leading to anterior extremity of body; three groups (1 median and 2 lateral) of well-developed posterior glands between vitellaria and squamodiscs; glands opening posteriorly at level of anchors (Fig. 4). Two pairs of dorsal ocelli, anterior pair less developed. Mouth anterior, subterminal and ventral. Pharynx median subspherical, 52-80 (62 $\pm 12, \mathrm{n}=11)$ long, 45-50 (48 \pm 2 , $\mathrm{n}=11$ ) wide. Oesophagus very short; oesophageal glands present. Two simple lateral intestinal caeca, not united posteriorly. Short haptoral peduncle present. Haptor trapezoidal and slightly asymmetrical. Squamodiscs 80-110 (93 $\pm 15, \mathrm{n}=14)$ in diameter with $12-13$ concentric rows of rodlets; 1-2 innermost row V-shaped and closed; rodlets, except those of two central rows, bearing median blunted spur. Dorsal anchors with incipient guard, straight blade and short point; a: 36-47 $(43 \pm 2), b: 36-45(40 \pm 2)$, c: $15-25(20 \pm 2), n=20$. Two lateral dorsal bars with flattened medial extremity 60-80 (71 $\pm 3, \mathrm{n}=20)$ long, $10-20(15 \pm 2, \mathrm{n}=20)$ wide. Ventral anchors with developed handle, wide guard, bent shaft and short point; a: 50-55 (53 \pm 1$)$, b: 45-55 (49 \pm 1$), \mathrm{c}: 23-40$ (32 \pm 2$), \mathrm{d}: 18-30(23 \pm 2)$, f: $12-22(17 \pm 2), \mathrm{g}: 12-20(16 \pm 1),(\mathrm{n}=22)$. Ventral transverse bar, 93-125 (112 $\pm 4, \mathrm{n}=21)$ long, with small median constricted portion and tapered ends, 10 $18(14 \pm 1, \mathrm{n}=1)$ wide. Fourteen uncinuli (seven pairs)
12-13 long; three ventral and two dorsal on lateral haptoral lobes; two ventral between anchors.

Subspherical testis posterior and intercaecal. Vas deferens emerging from antero-sinistral part of testis; seminal vesicle in middle region of the body as conspicuous dilation of vas deferens. Prostatic glands lateral, right prostatic reservoir muscular. Male quadriloculate copulatory organ reniform, with heavily sclerotized bulb divided into four chambers, 75-120 (98 \pm $6, \mathrm{n}=15)$ maximum length; first chamber with subcircular zone (aperture?); last chamber forming short cone 17-25 (21 $\pm 1, \mathrm{n}=15)$ long, extended by thin sclerotized tube $35-45(41 \pm 1, \mathrm{n}=15)$ long; cirrus present, sometimes everted at tip of tube. Ovary on right side, looping dorsoventrally right intestinal caecum. Sclerotized vagina sinistral, $75-120(97 \pm 9, \mathrm{n}=16)$, maximum length. Vagina with trumpet followed by thinly sclerotized primary canal; canal wall irregular and annulated on its anterior part; canal forms one loop and continues by a part with regular wall and connects to very small primary chamber; spherical sclerotized secondary chamber, $10-13(12 \pm 1, \mathrm{n}=16)$ in diameter communicates with primary chamber via thin secondary canal; secondary chamber continued anteriorly by accessory structure forming single loop. Protuberances on surface of secondary chamber (Fig. 3E). Vitelline follicles lateral, coextensive with intestinal caeca and contiguous posterior to testis. Ootype on right side opening at median genital pore. Eggs reniform with thickest shell at proximal pole, polar filament absent, 130-190 (157 \pm $12, \mathrm{n}=8)$ long, 50-90 $(70 \pm 8, \mathrm{n}=8)$ wide.

Ty pe host: Epinephelus costae (Steindachner, 1878).

I $\mathrm{n} \mathrm{fection}$ s it e : Gills, between secondary lamellae.

Type 1 oc ality: $\operatorname{Sfax}\left(34^{\circ} 45^{\prime} \mathrm{N}, 10^{\circ} 05^{\prime} \mathrm{E}\right)$.

O t h e r 1 o c a 1 i t i e s : Zarzis $\left(33^{\circ} 15^{\prime} \mathrm{N}, 11^{\circ} 10^{\prime} \mathrm{E}\right)$

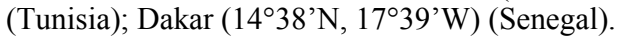

Preva 1 e n c e : $84 \%$ (examined 19 , infected 16 ).

H o 1 o t y p e : MNHN no. HEL 4 (Th 77).

$\mathrm{P}$ a r a t y p e s : MNHN no. HEL 5 (Th 78), MNHN no. HEL 6 (Th 79); BMNH no. 2007.3.12.2, BMNH no. 2007.3. 12.3; IPC no. M-436.

E t y m o log y: The name refers to the size of the vagina and is derived from the Greek words "dolicos" meaning long and "colpos" vagina.

\section{Remarks}

Pseudorhabdosynochus dolicocolpos is readily distinguished by the shape of its sclerotized vagina, which has a long duct, and its slightly asymmetrical haptor. The asymmetry, on the left or right side of the haptor, may reflect a mode of gill attachment allowing this worm to avoid competition for microhabitat in the presence of its congeners. Three other species, $P$. hirudineus Justine, 2005, $P$. euitoe Justine, 2006, and $P$. epinepheli Yamaguti, 1958 (as redescribed by Kritsky et BeverleyBurton 1986) have vagina similar to that of $P$. dolicocolpos, characterized by a long primary canal, but they differ by details of the morphology and by a symmetrical haptor. 

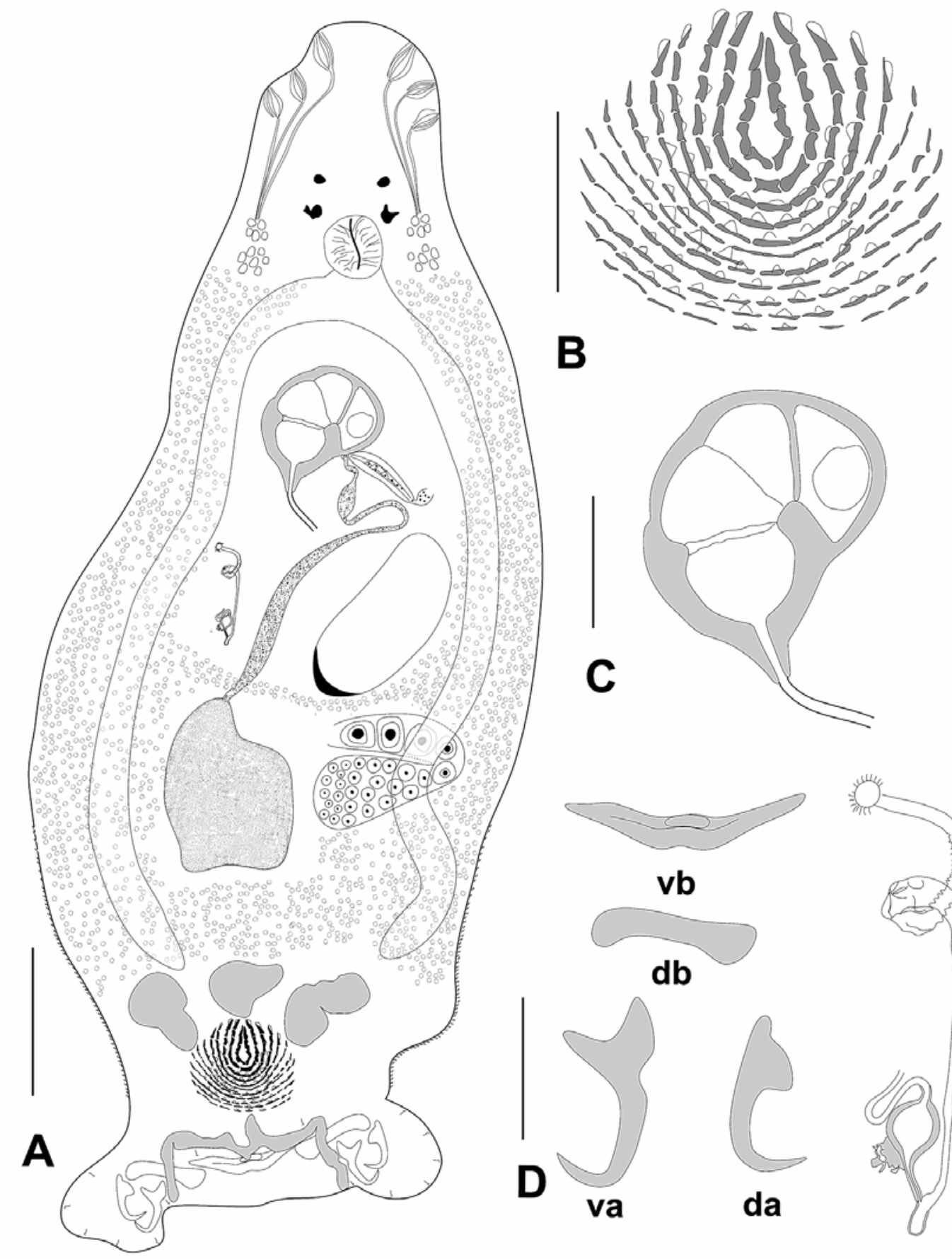

B
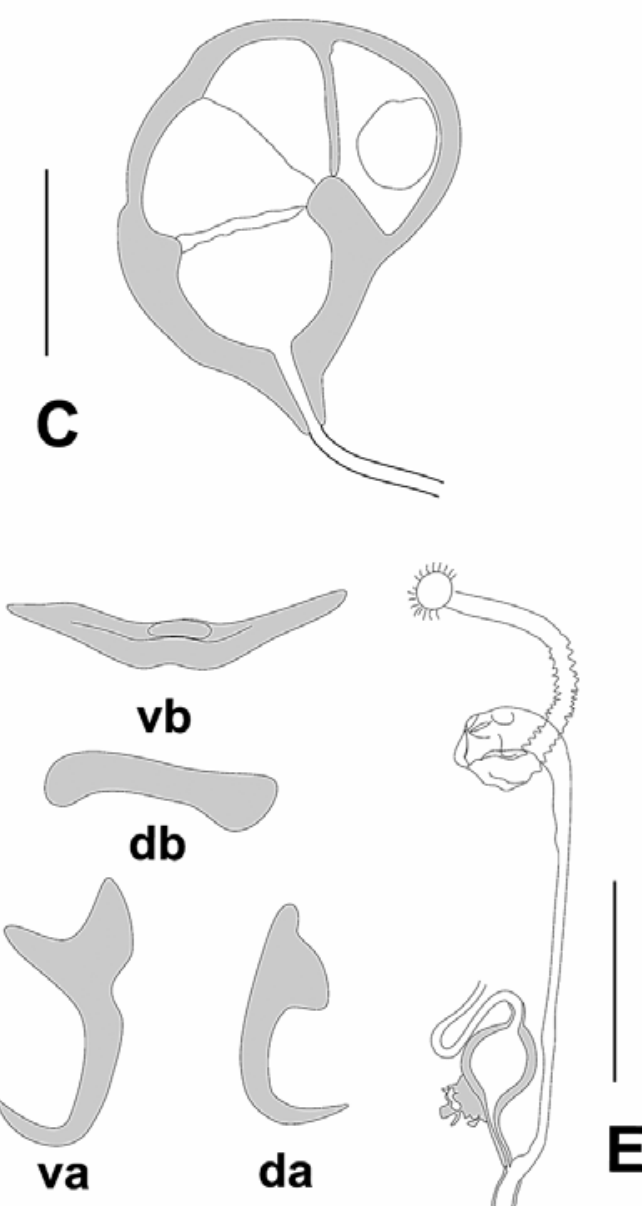

Fig. 3. Pseudorhabdosynochus dolicocolpos sp. n. A - habitus, dorsal view, composite drawing of live specimens; B - dorsal squamodisc; C - male quadriloculate copulatory organ; D - haptoral sclerite (vb - ventral bar; db - dorsal bar; va - ventral anchors; da - dorsal anchors); E - sclerotized vagina. Scale bars: Fig. A $=100 \mu \mathrm{m}$; Figs. B-E $=50 \mu \mathrm{m}$.

\section{Pseudorhabdosynochus enitsuji sp. n.}

Fig. 5

Description (based on 19 flattened specimens). Di-

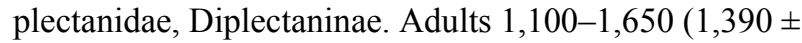
$110, \mathrm{n}=11)$ long, including haptor; maximum width $300-650(460 \pm 67, n=11)$ at level of ovary. Tegument smooth. Two groups of cephalic glands on each side of pharynx, both with ducts leading to six paired lateral head organs. Posterior glands less developed, opening posteriorly at level of anchors. Two pairs of dorsal ocelli, anterior pair less developed. Mouth anterior, subterminal and ventral. Pharynx median elliptical; 80$100(88 \pm 7, \mathrm{n}=17)$ long, $60-85(76 \pm 6, \mathrm{n}=17)$ wide. 


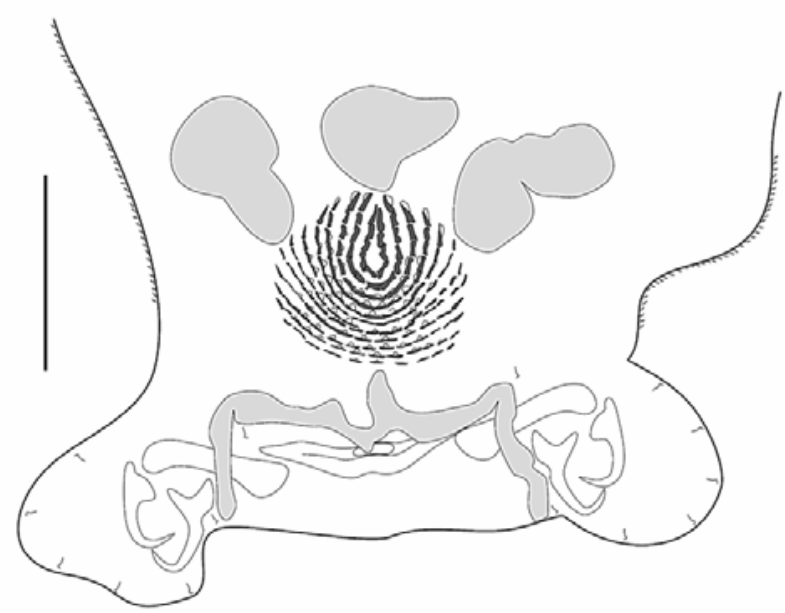

Fig. 4. Pseudorhabdosynochus dolicocolpos sp. n. Posterior part of the body showing posterior gland and asymmetrical haptor. Scale bar $=100 \mu \mathrm{m}$.

Oesophagus very short; oesophageal glands present. Two simple lateral intestinal caeca, not united posteriorly. Haptoral peduncle present. Haptor trapezoidal. Dorsal and ventral squamodiscs subspherical 100-120 $(105 \pm 6, \mathrm{n}=7)$ long, $90-100(94 \pm 4, \mathrm{n}=7)$ wide with 14-16 (15 $\pm 1, \mathrm{n}=7)$ rows of rodlets; 3-4 innermost rows V-shaped and closed. Dorsal anchors with incipient guard, straight blade and short point; a: 45-52 (50 \pm $2)$, b: 43-50 (47 \pm 2$)$, c: $20-25(24 \pm 1), n=14$. Two lateral dorsal transverse bars with spatulate medial end $70-85(80 \pm 3, \mathrm{n}=14)$ long, $12-17(14 \pm 1, \mathrm{n}=14)$ median wide. Ventral anchors with developed handle, wide guard, bent shaft and short point; a: 62-72 (66 \pm 2), b: 58-65 (61 \pm 2$),$ c: $37-45$ (42 \pm 2$), d: 25-35$ (29 \pm 2), f: $20-30(26 \pm 2)$, g: 15-23 $(20 \pm 1)$, $(n=14)$. Ventral transverse bar $130-160(138 \pm 5, \mathrm{n}=16)$ long, with little medial constricted portion and tapered ends, 10-17 $(15 \pm 1, \mathrm{n}=16)$ wide. Fourteen uncinuli (seven pairs) 13-14 long.

Subspherical testis posterior and intercaecal. Seminal vesicle in middle region of the body as conspicuous dilation of vas deferens. Prostatic glands lateral, right prostatic reservoir muscular. Male quadriloculate copulatory organ with large sclerotized bulb divided into four chambers $140-210(155 \pm 7, \mathrm{n}=16)$ maximum length; first with subcircular zone (aperture?); last forms short cone 10-15 $(12 \pm 1, \mathrm{n}=16)$ long, extended by thin sclerotized tube 55-70 $(58 \pm 2, \mathrm{n}=16)$ long; cirrus present, sometimes everted at tip of tube $(55-60, \mathrm{n}=2)$ long. Ovary on right side, looping dorsoventrally around right intestinal caecum. Sclerotized vagina sinistral, 40 $45(42 \pm 1, \mathrm{n}=19)$ maximum length. Vagina with anterior trumpet followed by heavily sclerotized primary canal bordering spherical primary chamber. Canal and chamber communicating via very thin canal. Chamber 25-30 (27 $\pm 1, \mathrm{n}=19)$ in diameter, with heavily sclerotized wall and posterior protuberances (Fig. 5E).
Vitelline follicles lateral, coextensive with intestinal caeca and contiguous posterior to testis. Ootype on right side, opening at median genital pore. Eggs reniform with thickest shell at proximal pole, polar filament absent, 120-230 (193 $\pm 26, \mathrm{n}=7)$ long, $70-90(80 \pm 5, \mathrm{n}=$ 7) wide.

Type host: Epinephelus costae (Steindachner, 1878).

In fe c t i o n s it e : Gills, between secondary lamellae.

Type 1 oc ality: $\operatorname{Sfax}\left(34^{\circ} 45^{\prime} \mathrm{N}, 10^{\circ} 05^{\prime} \mathrm{E}\right)$.

O t h e r 1 o c a 1 i t i e s : Zarzis $\left(33^{\circ} 15^{\prime} \mathrm{N}, 11^{\circ} 10^{\prime} \mathrm{E}\right)$

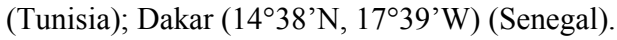

Preva 1 e n c e : $73 \%$ (examined 19 , infected 14 ).

Ho lo ty p e : MNHN no. HEL 7 (Th 80).

$\mathrm{P}$ a r a t y p e $\mathrm{s}:$ MNHN no. HEL 8 (Th 81 ), MNHN no. HEL 9 (Th 82); BMNH no. 2007.3.12.4; IPC no. M-437.

E t y m o lo g y: The species is named in honour of Professor J.-L. Justine in recognition of his great contribution to the knowledge of biology and systematics of Monogenea (enitsuji is an anagram of Justine).

\section{Remarks}

Pseudorhabdosynochus enitsuji differs from P. bouaini by the morphology of its vaginal duct, which is straight, constricted in the middle, and bordering the spherical primary chamber. In addition, the ventral bar is longer in $P$. enitsuji than $P$. bouaini (130-160 vs 93125).

Due to the morphology of vagina with a heavily sclerotized spherical primary chamber, $P$. enitsuji can be grouped with $P$. kritskyi Dyer, Williams et BunkleyWilliams, 1994 (as redescribed by Tingbao et al. 2005) and $P$. capurroi Vidal-Martínez et Mendoza-Franco, 1998. However, it can be distinguished from P. kritskyi and $P$. capurroi by the morphology and the size of male copulatory organ (155 vs 118 and 229, respectively)

Pseudorhabdosynochus auitoe Justine, 2006 and $P$. venus Hissinger et Justine, 2005 differ from $P$ enitsuji by the morphology of the second part of the vagina, characterized by a secondary canal and a small secondary chamber.

\section{Pseudorhabdosynochus sinediscus sp. n. Fig. 6}

Description (based on 13 flattened specimens). Diplectanidae, Diplectaninae. Adults 1,050-1,400 (1,200 \pm $68, \mathrm{n}=10)$ long, including haptor; maximum width $200-280(245 \pm 20, \mathrm{n}=10)$ at level of ovary. Tegument smooth. Two groups of cephalic glands, on each side of pharynx; numerous ducts lead from these glands to three prominent apertures which open ventrally on either side of anterolateral margin of head (head organs). Single anteromedian gland present leading to anterior extremity of body. Posterior glands not observed. Two pairs of dissimilar dorsal ocelli. Mouth anterior, subterminal and ventral. Pharynx median subspherical, 57-70 (64 $\pm 4, \mathrm{n}$ $=11)$ long, 45-60 (52 $\pm 6, \mathrm{n}=11)$ wide. Oesophagus very short; oesophageal glands present. Two simple lateral intestinal caeca not united posteriorly. Haptoral 

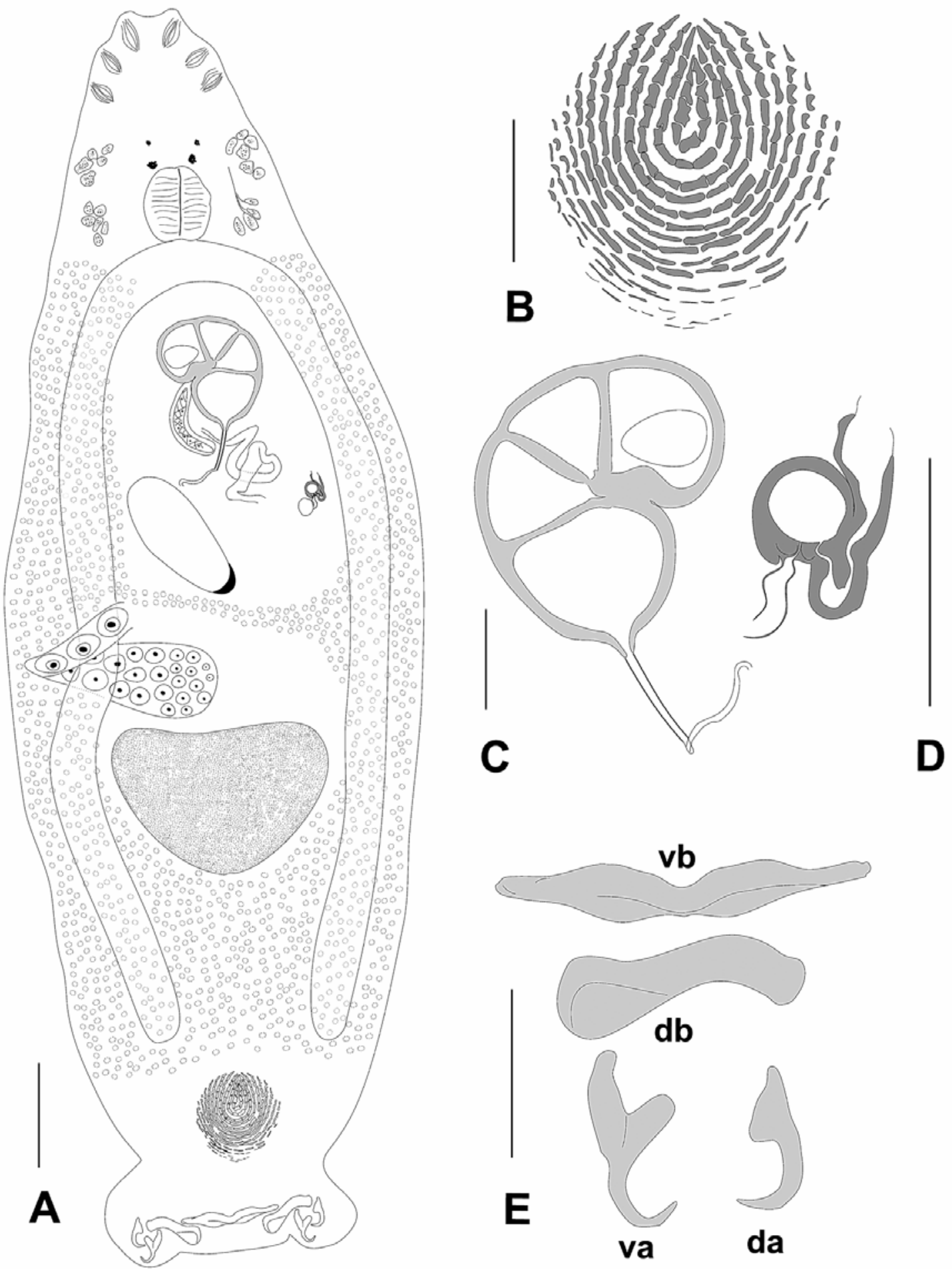

Fig. 5. Pseudorhabdosynochus enitsuji sp. n. A - habitus, ventral view, composite drawing of live specimens; B - dorsal squamodisc; $\mathbf{C}$ - male quadriloculate copulatory organ; D - sclerotized vagina; $\mathbf{E}$ - haptoral sclerite (vb - ventral bar; $\mathrm{db}$ - dorsal bar; va - ventral anchors; da - dorsal anchors). Scale bars: Fig. A $=100 \mu \mathrm{m}$; Figs. B-E $=50 \mu \mathrm{m}$.

peduncle present. Haptor trapezoidal. Dorsal and ventral squamodiscs absent. Dorsal anchors with incipient guard, straight blade and short point; a: 50-55 (53 \pm 1$)$, b: $48-54(51 \pm 1), \mathrm{c}: 22-30(26 \pm 1), \mathrm{n}=16$. Two lateral dorsal transverse bars with flattened medial extremity, 60-90 (67 $\pm 3, \mathrm{n}=16)$ long, 10-22 $(14 \pm 2, \mathrm{n}=16)$ wide. Ventral anchors with developed handle, wide guard, bent shaft and short point; a: 57-68 (62 \pm 2$)$, 

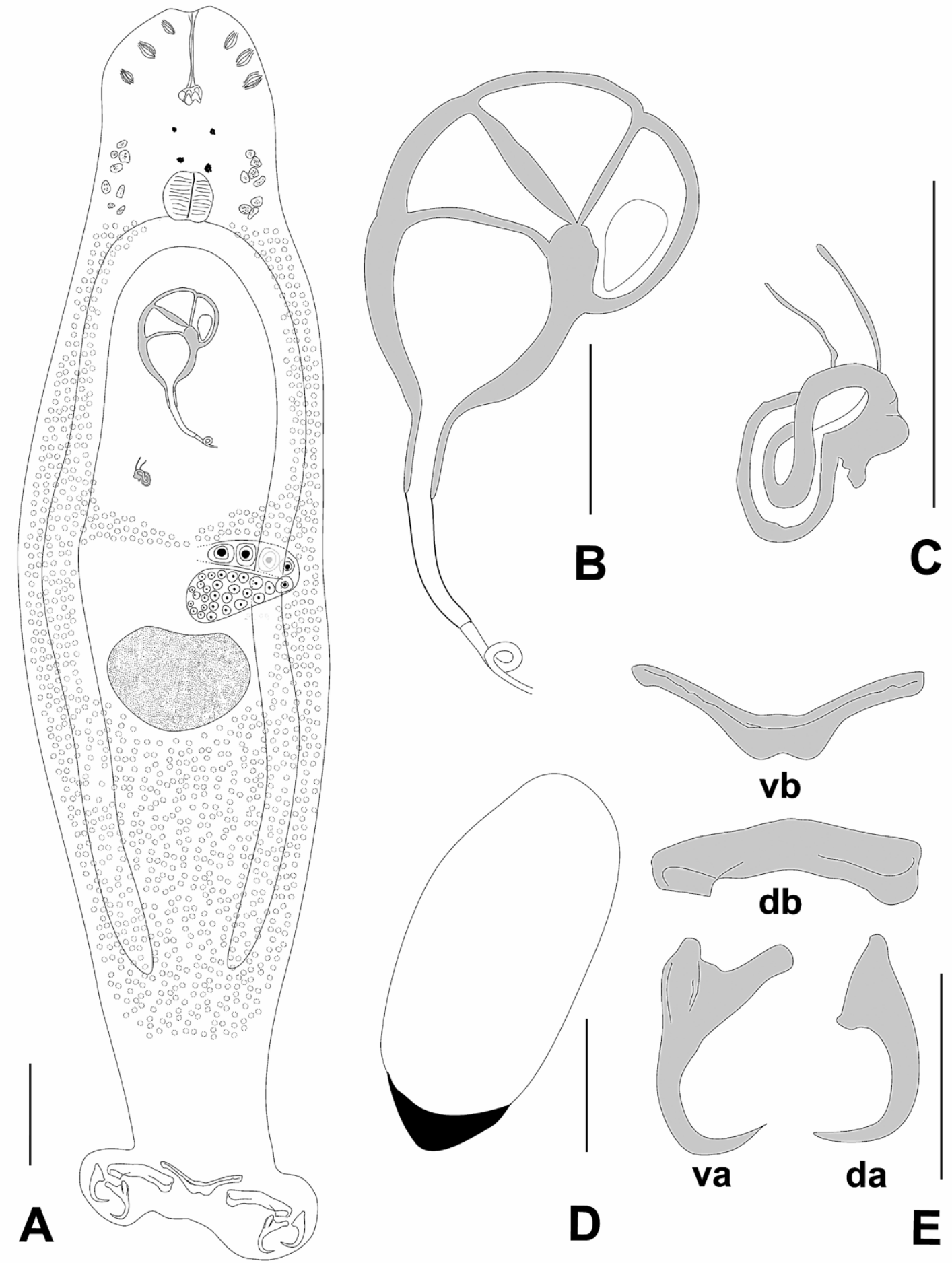

D

E

Fig. 6. Pseudorhabdosynochus sinediscus sp. n. A - habitus, dorsal view, composite drawing of live specimens; $\mathbf{B}-\mathrm{male}$ quadriloculate copulatory organ; $\mathbf{C}$ - sclerotized vagina; $\mathbf{D}$ - egg; $\mathbf{E}$ - haptoral sclerite (vb - ventral bar; db - dorsal bar; va - ventral anchors; da -dorsal anchors). Scale bars: Fig. A $=100 \mu \mathrm{m}$; Figs. B-E $=50 \mu \mathrm{m}$.

b: 50-63 (56 \pm 2$), \mathrm{c}: 45-52(49 \pm 1), \mathrm{d}: 24-34(26 \pm 2)$, f: $4-8(6 \pm 1), \mathrm{g}: 10-20(16 \pm 2),(\mathrm{n}=16)$. Ventral transverse bar V-shaped 70-95 $(86 \pm 3, \mathrm{n}=16)$ long, with small median constricted portion and tapered ends, $10-15(13 \pm 1, \mathrm{n}=16)$ wide. Fourteen uncinuli (seven pairs) 13-14 long.
Subspherical testis posterior and intercaecal. Vas deferens emerging from antero-sinistral part of testis; seminal vesicle in middle region of body as conspicuous dilation of vas deferens. Prostatic glands lateral, right prostatic reservoir muscular. Male quadriloculate copulatory organ reniform with large sclerotized bulb di- 
vided into four chambers 80-110 (99 $\pm 6, \mathrm{n}=10)$ maximum length; first with subcircular zone (aperture?); last forms short cone 20-30 (24 $\pm 3, \mathrm{n}=10)$ long, extended by thin sclerotized tube $32-55$ (42 \pm 4 , $n$ $=10$ ) long; cirrus present, everted at tip of tube and looping at distal extremity. Ovary on right side, looping dorsoventrally around right intestinal caecum. Vagina sclerotized 35-50 (39 $\pm 4, \mathrm{n}=18)$ maximum length. Sclerotized vagina with anterior large trumpet prolonged by heavily sclerotized S-shaped primary canal, looping once, and enlarging distally to form small primary chamber; protuberance on distal surface of this chamber (Fig. 6C). Vitelline follicles lateral, coextensive with intestinal caeca and contiguous posteriorly to testis. Ootype on right, opening at median genital pore. Eggs reniform with thickest shell at proximal pole, polar filament absent, 140-150 $(\mathrm{n}=3)$ long, 60-75 $(\mathrm{n}=$ 3) wide.

T y p e host: Epinephelus costae (Steindachner, 1878).

In f e c t i o n s i t e : Gills, between secondary lamellae.

Ty p e 1 o c a 1 ity: $\operatorname{Sfax}\left(34^{\circ} 45^{\prime} \mathrm{N}, 10^{\circ} 05^{\prime} \mathrm{E}\right)$.

O t h e r 1 o c a 1 i t i e s : Zarzis $\left(33^{\circ} 15^{\prime} \mathrm{N}, 11^{\circ} 10^{\prime} \mathrm{E}\right)$ (Tunisia).

Prevale n c e: $71 \%$ (examined 7 , infected 5).

H o 1 o t y p e : MNHN no. HEL 11 (Th 84).

$\mathrm{P}$ a r a t y p e s : BMNH no. 2007.3.12.5; IPC no. M-438.

E t y m o l o g y: The name refers to the absence of squamodiscs and is derived from the Latin "sine", indicating absence, and "discus", contraction of "squamodiscus".

\section{Remarks}

This is the first mention of a species of Pseudorhabdosynochus lacking squamodiscs. This parasite can be easily recognized by this character.

This species is apparently the least abundant Pseudorhabdosynochus species found on E. costae. We did not find this species in the material from Senegal.

\section{Pseudorhabdosynochus sosia sp. n.}

Fig. 7

Description (based on 34 flattened specimens). Diplectanidae, Diplectaninae. Adults 800-1,300 (1,100 \pm $72, \mathrm{n}=24)$ long, including haptor; maximum width $170-350(270 \pm 22, \mathrm{n}=24)$ at level of ovary. Tegument smooth. Two groups of cephalic glands, on each side of pharynx; numerous ducts leading from these glands to three prominent apertures which open ventrally on either side of anterolateral margin of head. Single anteromedian gland present, leading to anterior extremity of body. Posterior glands not observed. Two pairs of dissimilar dorsal ocelli. Mouth anterior, subterminal and ventral. Pharynx median subspherical 50-80 (66 $\pm 5, \mathrm{n}$ $=14)$ long, 40-70 (57 $\pm 4, \mathrm{n}=14)$ wide. Oesophagus very short or absent; oesophageal glands present. Two simple lateral intestinal caeca not united posteriorly. Haptoral peduncle present. Haptor trapezoidal. Dorsal and ventral circular squamodiscs $60-80(67 \pm 3, \mathrm{n}=12)$ in diameter; 10-11 rows of rodlets; 1-2 innermost rows forming circle; rodlets, except those of two central rows, bearing sharp median spur. Dorsal anchors with incipient guard, straight blade and short point; a: 50-57 (52 \pm 2), b: 45-53 (49 \pm 1$), \mathrm{c}: 23-30(26 \pm 1), \mathrm{n}=28$. Two latero-dorsal transverse bars with flattened medial extremity, 58-73 (66 $\pm 2, \mathrm{n}=36)$ long, $12-22(14 \pm 2, \mathrm{n}=$ 36) median wide. Ventral anchors with developed handle, wide guard, bent shaft and short point; a: 55-67 (60 $\pm 1)$, b: 50-64 (55 \pm 1$)$, c: 37-53 (45 \pm 2$), \mathrm{d}: 20-30$ (26 $\pm 1)$, f: $5-15(9 \pm 1)$, g: $12-22(18 \pm 1), \mathrm{n}=34$. Ventral transverse bar 70-105 (83 $\pm 3, \mathrm{n}=34)$ long, 7-17 (12 \pm $1, \mathrm{n}=34$ ) wide. Fourteen uncinuli (seven pairs) 14-17 long; three ventral and two dorsal pairs on lateral haptoral lobes; two ventral pairs between anchors.

Subspherical testis, posterior and intercaecal. Vas deferens emerging from antero-sinistral part of testis, seminal vesicle in middle region of body as conspicuous dilation of vas deferens. Prostatic glands lateral; right prostatic reservoir muscular. Male quadriloculate copulatory organ with large sclerotized bulb divided into four chambers 90-130 (110 $\pm 3, \mathrm{n}=29)$ maximum length; first with large subcircular zone (aperture?); last forming short cone 10-17 (13 $\pm 1, \mathrm{n}=29)$ long, extended by thin sclerotized tube $25-45(38 \pm 2, \mathrm{n}=29)$ long; cirrus present, sometimes everted at tip of tube (65 long). Ovary on right side, looping dorsoventrally around right intestinal caecum. Sclerotized vagina sinistral, 40-55 (48 $\pm 1, \mathrm{n}=34)$ maximum length. Sclerotized vagina with large trumpet prolonged by thin sclerotized S-shaped primary canal, looping once, and enlarging to form oval primary chamber with heavily sclerotized wall; primary chamber connected to second heavily sclerotized spherical chamber by very thin secondary canal; small protuberances on distal surface of secondary chamber (Fig. 7C). Vitelline follicles lateral, coextensive with intestinal caeca and contiguous posterior to testis. Ootype on right side, opening at median genital pore. Eggs reniform with thickest shell at proximal pole, polar filament absent, 130-195 (165 $\pm 6, \mathrm{n}=$ 19) long, 50-83 $(67 \pm 4, \mathrm{n}=19)$ wide.

Ty pe host: Epinephelus costae (Steindachner, 1878).

I $\mathrm{n} \mathrm{fecti}$ o n sit e : Gills, between secondary lamellae.

Type locality: Sfax $\left(34^{\circ} 45^{\prime} \mathrm{N}, 10^{\circ} 05^{\prime} \mathrm{E}\right)$.

O t h e r 1 o c a 1 i t i e s : Zarzis $\left(33^{\circ} 15^{\prime} \mathrm{N}, 11^{\circ} 10^{\prime} \mathrm{E}\right)$

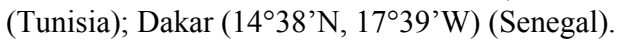

Prevale n c e : $94 \%$ (examined 19 , infected 18 ).

H o 1 o t y p e : MNHN no. HEL 11 (Th 84).

P a r a t y p e s : MNHN no. HEL 12 (Th 85), MNHN no. HEL 13 (Th 86); BMNH no. 2007.3.12.6; IPC no. M-439.

E t y m o 1 o g y: The specific name refers to Sosia, who in Plautus' comedy Amphitryon confronts his double, and to the resemblance of the vagina of $P$. sosia to that of $P$. beverlyburtonae. 


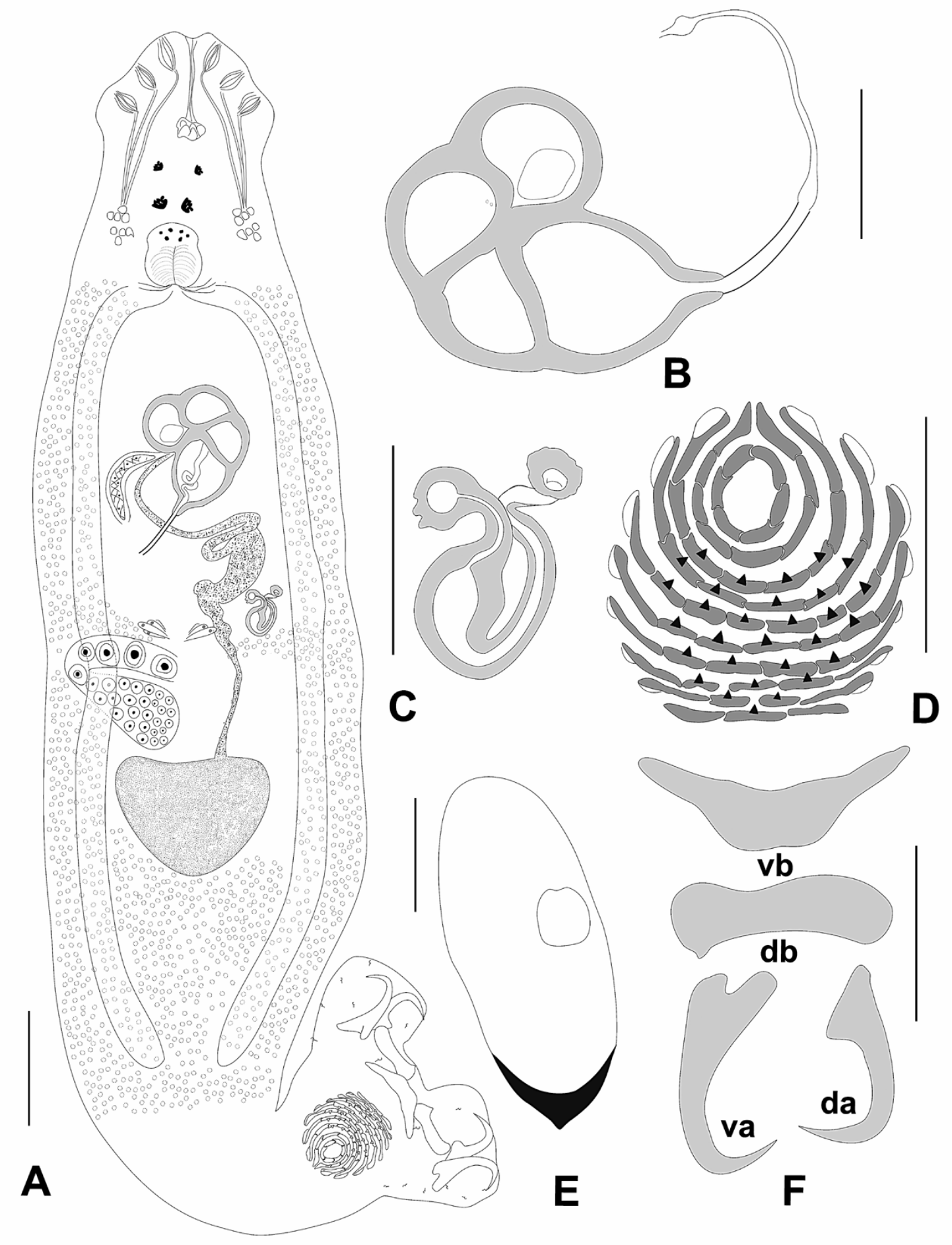

Fig. 7. Pseudorhabdosynochus sosia sp. n. A - habitus, ventral view, composite drawing of live specimens; B - male quadriloculate copulatory organ; $\mathbf{C}$ - sclerotized vagina; D - dorsal squamodisc; $\mathbf{E}$ - egg; $\mathbf{F}$ - haptoral sclerite (vb - ventral bar; db - dorsal bar; va - ventral anchors; da - dorsal anchors). Scale bars: Fig. A $=100 \mu \mathrm{m}$; Figs. B-F $=50 \mu \mathrm{m}$.

\section{Remarks}

The vaginal morphology of $P$. sosia resembles that of $P$. beverleyburtonae. However, $P$. sosia can be distin-

guished by the size and the thickness of the wall of the first vaginal chamber. 


\section{DISCUSSION}

As mentioned by Santos et al. (2000) and Justine (2005b), the nomenclature of diplectanid parasites of Epinephelus "is very confused". We agree with Kritsky and Beverley-Burton (1986) and consider Cycloplectanum Oliver, 1968 a junior subjective synonym of $P$ seudorhabdosynochus Yamaguti, 1958. The original description of the type species, Pseudorhabdosynochus epinepheli Yamaguti, 1958, contains some errors in morphology and anatomy. These errors are present in the diagnosis of the genus provided by Yamaguti (1963). After examination of the type and paratype of Diplectanum epinepheli Yamaguti, 1938 and Pseudorhabdosynochus epinepheli Yamaguti, 1958, Kritsky and Beverley-Burton (1986) corrected these errors, but the diagnosis of the genus was not amended.

Several works concerning the systematics of Pseudorhabdosynochus have emphasized the importance of the morphology of the sclerotized vagina for distinguishing species (Beverly-Burton and Suriano 1981, Dyer et al. 1995, Vidal-Martínez et al. 1997, Santos et al. 2000, Zhang et al. 2001, Justine 2005b and Yang et al. 2005). The squamodisc structure is also an important criterion.

In 2001, when we began the study of parasites of $E$. costae, the absence of squamodiscs in some Pseudorhabdosynochus species had been considered teratologic. Diplectanid specimens lacking squamodiscs were observed on five E. costae (three in 2004 and two in 2005). These parasites with quadriloculate male copulatory organs are placed into Pseudorhabdosynochus and described above as $P$. sinediscus.

After our study of both previously and newly described species of Pseudorhabdosynochus, we propose an amended diagnosis of the genus as follows:

\section{Pseudorhabdosynochus Yamaguti, 1958, (amended)}

Diplectanidae, Diplectaninae. Tegument smooth or armed with scales. Haptor with two pairs of anchors; three transverse bars, two latero-dorsal and one medioventral; 14 uncinuli. Two squamodiscs, present or absent, one ventral and one dorsal. Rodlets with or without median blunted spur. Vas deferens sinistral, not looping around intestinal caecum. Male copulatory organ quadriloculate, sclerotized, comprising bulbous reniform part divided into four chambers, distal chamber with distal short cone, elongate curved tube, evaginable cirrus. Ovary looping dorsoventrally around right intestinal caecum. Vagina sclerotized, opening ventrally on left sublateral side. Eggs reniform or tetrahedral with long polar filament. Parasites of marine Teleostei. Type species: Pseudorhabdosynochus epinepheli Yamaguti, 1958.

The morphology of the male quadriloculate organ varies slightly and cannot be used herein for the distinction of Pseudorhabdosynochus species because it differs according to both the coverslip pressure applied and the angle of observation. However, Justine (2005a) com- mented upon a possible distinction based on a relative wall thickness of successive chambers.

In our work, we recognize two groups of Pseudorhabdosynochus according to the size of the quadriloculate organ, large in P. bouaini and P. enitsuji (174 and 155 , respectively) and small in $P$. dolicocolpos, $P$. sinediscus and $P$. sosia (99, 110 and 98, respectively).

The squamodiscs of Pseudorhabdosynochus species infecting $E$. costae are different. We recognize three morphologies: (1) squamodiscs with innermost rows of rodlets closed and forming a circle; rodlets with sharp spurs (P. sosia); (2) squamodiscs with innermost rows of rodlets V-shaped and closed; rodlets with blunted spurs ( $P$. dolicocolpos); (3) squamodiscs with innermost rows of rodlets $\mathrm{V}$-shaped, closed or not; rodlets without spurs ( $P$. bouaini and $P$. enitsuji). We relate each squamodisc morphology to a particular vaginal form: for morphology (1), S-shaped vagina with heavily sclerotized wall ( $P$. sosia); for morphology (2), vagina very long, less sclerotized ( $P$. dolicocolpos); for morphology (3), vagina with heavily sclerotized spherical chamber (P. bouaini and P. enitsuji). By the morphology of its vagina, $P$. sinediscus can be placed with $P$. sosia. In spite of this apparent correspondence, we suggest the major specific character used to differentiate species of Pseudorhabdosynochus to be the morphology of the vagina. More attention must be paid to the thickness of the walls of the vaginal chamber. Morphology of squamodiscs is not specific to Pseudorhabdosynochus spp.; we find the same morphology in species of Diplectanum and Echinoplectanum (Oliver 1987, Justine and Euzet 2006).

Our observations show that the anatomy of the quadriloculate male copulatory organ must be revised. In Pseudorhabdosynochus the first chamber possesses a subcircular (open?) zone with an unknown role; the anatomical connection between the vas deferens, the prostatic gland and the quadriloculate organ is not clear, and the operation of the male copulatory organ remains a mystery. We have not seen the genital pore as described by Yang et al. (2005).

Spermatozoa have never been observed in the sclerotized vaginal chamber of any of the species. Dyer et al. (1995) and Vidal-Martínez et al. (1997) attribute to this chamber the role of seminal receptacle, but we do not agree with these authors.

Posterior glands seem to be present in all of the five species but are rarely well developed, except for $P$. dolicocolpos in which ducts leading from this gland are seen extending to the posterior end of the haptor.

The five species of Pseudorhabdosynochus described herein are the first species of Monogenea reported from $E$. costae. The number of species co-occurring in a single host species is not consistent with the results of investigations of Pseudorhabdosynochus diversity in other Mediterranean groupers; 1 species (P. hargisi) for $E$. aeneus and 2 ( $P$. beverleyburtonae, $P$. riouxi) for $E$. marginatus Oliver (1987). 
Key to the species of Pseudorhabdosynochus from

\section{Epinephelus costae}

1 Haptor without squamodiscs ................ Pseudorhabdosynochus sinediscus

- Haptor with two squamodiscs ....................... 2

2 Vagina very long, $>90 \mu \mathrm{m}$........................... Pseudorhabdosynochus dolicocolpos

- Maximum length of vagina $<70 \mu \mathrm{m}$............... 3

3 Vagina S-shaped, with ovoid chamber Pseudorhabdosynochus sosia

- Vagina with heavily sclerotized spherical chamber ... .................................................... 4
4 Vaginal duct anterior to spherical chamber Pseudorhabdosynochus bouaini

- Vaginal duct bordering spherical chamber ... Pseudorhabdosynochus enitsuji

Acknowledgements. We thank Professor A. Bouain for invaluable support, Professors A. Raibaut and J.-L. Justine for collecting diplectanids from Epinephelus costae from Dakar, and $\mathrm{J}$. Cassonne from MNHN for sending the syntype of $P$. beverleyburtonae. The authors are grateful to T. Baker for a revision of the English.

\section{REFERENCES}

BEVERLEY-BURTON M., SURIANO D.M. 1981: A revision of Cycloplectanum Oliver, 1986 (Monogenea: Diplectanidae) and descriptions of $C$. hongkongensis and C. lantauensis n. sp. from Epinephelus spp. (Serranidae) in the South China Sea. Can. J. Zool. 59: 1276-1285.

Bu S.S.H., LEONG T.S., WONG S.Y., WOO Y.S.N., FOO R.W.T. 1999: Three diplectanid monogeneans from marine finfish (Epinephelus spp.) in the Far East. J. Helminthol. 73: 301312.

DYER W.G., WiLliams E.H. JR., BunKLEY-WiLliams L. 1995: Pseudorhabdosynochus monaensis $\mathrm{n}$. sp. (Monogenea: Diplectanidae) on Rock Hind from Mona Island, Puerto Rico. J. Aquat. Anim. Health 6: 59-63.

EuZet L., Oliver G. 1966: Diplectanidae (Monogenea) des Téléostéens de la Méditerranée occidentale. III. Quelques Lamellodiscus Jonhston et Tiegs, 1922, parasites de poissons du genre Diplodus (Sparidae). Ann. Parasitol. Hum. Comp. 41: 573-598.

FAO, Fisheries Department 1997: Aquaculture development FAO Technical Guidelines for Responsible Fisheries 5: 1-47.

GuSSEV A.V. 1962: Monogenoidea. In: E. Bychovskaya-Pavlovskaya et al. (Eds.), Key to the Parasites of Freshwater Fish of the USSR. Publ. House of Academy of Sciences of the USSR, Moscow-Leningrad, 919 pp. [Translated from Russian by IPST, SER N ${ }^{\circ} 1136$, Jerusalem, 1964.$]$

HEEMSTRA P.C., RANDALl J.E. 1993: FAO Species Catalogue. Groupers of the world (family Serranidae, subfamily Epinephelinae). An annotated and illustrated catalogue of the grouper, rockcod, hind coral grouper and lyretail species known to date. FAO Fisheries synopsis 125, 16, 382 pp.

Justine J.-L. 2005a: Species of Pseudorhabdosynochus Yamaguti, 1958 (Monogenea, Diplectanidae) from Epinephelus fasciatus and E. merra (Perciformes, Serranidae) off New Caledonia and other parts of the Indo-Pacific Ocean, with a comparison of measurements of specimens prepared with different methods and a description of $P$. caledonicus $\mathrm{n}$. sp. Syst. Parasitol. 62: $1-37$.

JUSTINE J.-L. 2005b: Pseudorhabdosynochus hirundineus n. sp. (Monogenea, Diplectanidae) from Variola louti (Perciformes, Serranidae) off New Caledonia. Syst. Parasitol. 62: 39-45.

JUSTINE J.-L., EUZET L. 2006: Diplectanids (Monogenea) parasitic on gills of the coralgroupers Plectropomus laevis and $P$. leopardus (Perciformes, Serranidae) off New Caledonia, with the description of five new species and the erection of Echinoplectanum n. g. Syst. Parasitol. 64: 147-172.

KRITSKY D.C., BEVERLEY-BURTON M. 1986: The status of Pseudorhabdosynochus Yamaguti, 1958 and Cycloplectanum
Oliver, 1968 (Monogenea: Diplectanidae). Proc. Biol. Soc. Wash. 99: 17-20.

MALMBERG G. 1957: Om förekomsten av Gyrodactylus på svenska fiskar. Skrifter Utgivna av Södra Sveriges Fiskeriförening, Årsskrift, (1956), 19-76. (In Swedish, with description of species and a summary in English.)

OLIVER G. 1987: Les Diplectanidae Bychowsky, 1957 (Monogenea, Monopisthocotylea, Dactylogyridea). Systématique. Biologie. Ontogénie. Écologie. Essai de Phylogenèse. Thèse, Académie de Montpellier, Université des Sciences et Techniques du Languedoc, Montpellier, $433 \mathrm{pp}$.

SANTOS C.P., BUChMANN K., GIBSON D.I. 2000: Pseudorhabdosynochus spp. (Monogenea: Diplectanidae) from the gills of Epinephelus spp. in Brazilian waters. Syst. Parasitol. 45: 145153.

TAK-SENG L., SeE-Yong W. 1988: A comparative study of the parasite fauna of wild and cultured grouper (Epinephelus malabaricus Bloch et Schneider) in Malaysia. Aquaculture 68: 203-207.

TingbaO Y., GibSON D.I., BiJIAN Z. 2005: Pseudorhabdosynochus summanoides $\mathrm{n}$. sp. (Monogenea: Diplectanidae) from Epinephelus coioides in Dapeng Bay, South China Sea, with observations on several similar species of Pseudorhabdosynochus Yamaguti, 1958. Syst. Parasitol. 62: 221-239.

VidAl-MartíneZ V.M., AguirRe-Macedo L., MENDOZAFRANCO E.F. 1997: Pseudorhabdosynochus yucatanensis sp. n. (Monogenea: Diplectanidae) from the gills of the red grouper Epinephelus morio (Pisces: Serranidae) of the Yucatan Peninsula, Mexico. Folia Parasitol. 44: 274-278.

Vidal-Martínez V.M., MendoZA-FranCo E. 1998: Pseudorhabdosynochus capurroi sp. n. (Monogenea: Diplectanidae) from gills of Mycteroperca bonaci (Pisces: Serranidae) of the Yucatan Peninsula, Mexico. Folia Parasitol. 45: 221-224.

YANG T.B., ZENG B.J., GIBSON D.I. 2005: Description of Pseudorhabdosynochus shenzhenensis $\mathrm{n}$. sp. (Monogenea: Diplectanidae) and redescription of $P$. serrani (Yamaguti, 1953) from Epinephelus coioides (Hamilton) off Dapeng Bay, Shenzhen, China. J. Parasitol. 91: 808-813.

YAMAGUTI S. 1963: Systema Helminthum. Vol. IV. Monogenea and Aspidocotylea. Interscience Publishers, New York, London, $699 \mathrm{pp}$.

YOUNG P.C. 1969: Some monogenoideans of the family Diplectanidae Bychowsky, 1957 from Australian teleost fishes. J. Helminthol. 43: 223-254.

ZHANG J.Y., YANG T.B., LIU L. 2001: Monogeneans of Chinese Marine Fishes. Agriculture Press, Beijing,. 400 pp. (In Chinese.) 